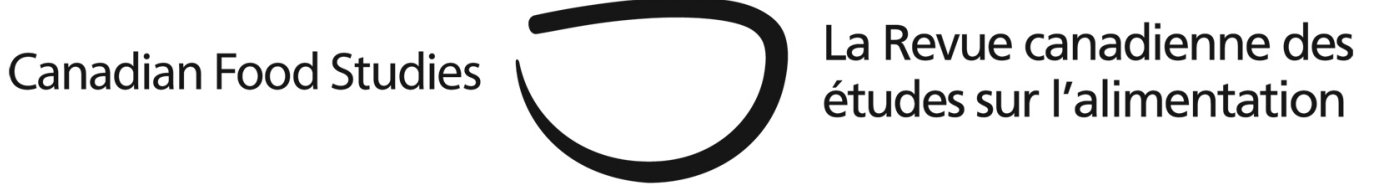

Field Report

\title{
From Food Mail to Nutrition North Canada: Reconsidering federal food subsidy programs for northern Ontario
}

\author{
Kristin Burnett, ${ }^{1}$ Kelly Skinner, ${ }^{2}$ and Joseph LeBlanc ${ }^{3}$ \\ ${ }^{1}$ Associate Professor, Department of Indigenous Learning, Lakehead University \\ 2 Postdoctoral Fellow, Department of Indigenous Learning, Lakehead University \\ 3 Independent Scholar
}

\begin{abstract}
This article evaluates federal food subsidy programs in northern Canada, focusing specifically on the transition from the Food Mail Program to Nutrition North Canada. Although the report on Nutrition North Canada by the Auditor General of Canada, Michael Ferguson, released on November 25, 2014, revealed some of the program's problems, we argue that the situation is far more complicated. In particular, the Auditor General's report focuses on the arctic regions and disregards the equally alarming state of food insecurity in the provincial Norths. ${ }^{1}$ By looking specifically at northern Ontario, this article outlines the diverse challenges and differences northerners face in ensuring access to affordable and nutritious food of good quality.
\end{abstract}

Keywords: food subsidy, Food Mail Program, Nutrition North Canada, Indigenous food insecurity, food quality, northern Ontario, provincial Norths

\footnotetext{
${ }^{1}$ Here we draw on Ken Coates and define the provincial Norths as: the sub-arctic band that lies south of the 60th parallel and stretches from Northern British Columbia through the Canadian shield to northern Labrador. The population of the provincial Norths is primarily Indigenous (comprised of a range of diverse cultures and peoples) and the economy is largely resource dependent. Significantly, the provincial Norths constitute almost one half of Canada's land mass (Coates, 1996; Coates, 2014). The Canadian Far North is defined as the geographical regions located above the $60^{\text {th }}$ parallel that are currently divided into Nunavut, the Northwest Territories, and the Yukon.
} 
Introduction

On November 25, 2014, the Auditor General of Canada (AG), Michael Ferguson, tabled his report on Nutrition North Canada (NNC), a subsidy program implemented by the federal government of Canada in April of 2011 to replace the long running Food Mail program (FMP), and designed to lower the cost of "perishable nutritious food" in northern communities as part of the "Government of Canada's Northern Strategy." Ferguson's announcement-that he intended to audit the brand-new program - came in August of 2013, in response to repeated calls from Indigenous grassroots and political organizations, unanimous motions passed by all three northern territorial legislatures, and a letter from the NDP Member of Parliament for the Northwest Territories, Dennis Bevington. In his report, the AG identified three areas of concern regarding the program: (1) determining community eligibility; (2) identifying whether or not retailers were passing on the full subsidy to customers; and (3) developing program management and measurement tools (Auditor General, 2014, p. iii). The two largest northern grocery retailers, the North West Company and Arctic Co-ops Ltd., strongly supported the AG's "recommendations for fixing the federal governments' Nutrition North Scheme" (APTN, 2014). The Minister of Aboriginal and Northern Development, Bernard Valcourt, said that he "welcomed the report... and accept[ed] the five recommendations" (Valcourt, 2014). The AG's report was also well received by many northern Indigenous groups and organizations that described the report as a "scathing review of the Nutrition North program" (APTN, 2014). While Ferguson certainly identified some of the key problems with the programparticularly around eligibility and tracking the application of the subsidy from the retailer to the customer-his report failed to clearly outline the breadth of the program's shortfalls. Moreover, the AG's review of the program does not illuminate the nature of the situation in the provincial Norths. Instead, most of the attention was paid to the Far North and in particular Nunavut which receives the vast majority of NNC subsidies, at forty-four percent (the next highest region is northern Quebec at eighteen percent) (NNC, 2013-2014a). There are twenty-five remote communities in Nunavut with approximately 33,000 residents (Government of Canada, 2013) and all of them are fully eligible for the NNC subsidy (NNC, 2014b). In comparison, northern Ontario has more remote First Nations than any other region in Canada (Government of Canada, 2014) — with thirty-two remote communities - only eight of which are eligible for the full NNC subsidy (NNC, 2014b).

While we are certainly not arguing that Nunavut is undeserving of the subsidy (indeed quite the opposite), we want to draw attention to the dangers of conflating the problems facing northern communities throughout Canada. Focusing on regional and provincial experiences rather than just "the North" further elucidates problems with the program, revealing that NNC is

\footnotetext{
${ }^{2}$ See official NNC website: http://www.nutritionnorthcanada.gc.ca/eng/1415385762263/1415385790537. The Northern Strategy has four components to it: exercise our Arctic sovereignty; protect our environmental heritage; promote social and economic development; and improve and devolve Northern governance. For more information see the federal government's website at: http://www.northernstrategy.gc.ca/index-eng.asp
} 
even less effective in regions like northern Ontario where communities received only twelve percent of NNC subsidies (NNC, 2013-2014a). Nor has the cost or quality of food demonstrably improved in those communities fortunate enough to be eligible for the full NNC subsidy. Instead, the subsidy is serving as more of a benefit to the retailer than consumers (Galloway, 2014). In particular, the report fails to account for the diverse challenges and differences northerners face across Canada in ensuring access to affordable and nutritious food of good quality.

The AG's report is merely an effort by the current conservative government to justify its decision to eliminate the previous longstanding Food Mail Program (FMP). This followed the recommendations of the 2008 Dargo Report—a report commissioned by the same government. According to the Dargo Report, the best way to lower the cost of food in northern communities was to eliminate the FMP and allow the free market system to operate properly in the regionand thus naturally lower the cost of food through competition (p. 29-31). The NNC was designed to serve as a cost containment measure in the face of the rising - but entirely necessary - costs of the FMP, and support the development of a market-based solution. Moreover, the federal government's proposition of a market-based solution is a difficult plan to implement, especially in northern communities where there is no retail competition, and often all goods and services - from food sales, to banking, to gas, to pharmacies - are managed by one retailer (Galloway, 2014, p. 397).

The NNC budget is now capped at \$54 million, in comparison to the budget of the FMP, which was between \$55 and \$58 million in its last year (Bell, 2011). Conveniently, on the Friday before the AG's report was released, the federal government announced an additional \$11.3 million in funding for NNC. That the federal government described the $\$ 11.3$ million as “additional funding” is misleading. The "additional” \$11.3 million only brings current NNC funding levels up to previous funding levels that existed under the former FMP (Bevington, 2015). A recent internal report released by Aboriginal Affairs and Northern Development Canada in early March 2015 recommended that funding for NNC should "at least be indexed to inflation or to changes in costs that are major contributors to the cost of food retailing in the North” (NNC, 2015).

What follows is a brief overview of food subsidy programs in northern Canada, an examination of program eligibility, and a discussion concerning the transition from FMP to NNC with a focus on northern Ontario. Finally, we take a look at two constant problems faced by many northerners regarding access to forest and freshwater foods and issues of food qualityneither of which can be addressed by food subsidy programs.

\section{Project context}

The research for this article is derived from a broader interdisciplinary research project that is community based and action oriented. The larger project pursues a number of different avenues of inquiry related to food security and sovereignty in northern Ontario and employs a mixed 
methodology. Drawing on the diverse skill set of the research team and community members, this article relies on government and corporate records (located at Library Archives Canada and the Provincial Archives of Manitoba), interviews and surveys conducted with community members and former Indian Affairs employees, newspapers, and the reports and studies conducted by Health Canada, the Food Mail program, Indian and Northern Affairs Canada, and various non-government organizations. Most of the reports and studies are available online.

The authors also have a great deal of personal and academic experience investigating food security in northern Canada. Kristin Burnett's research project looks at how government policy and corporate practices have manufactured food insecurity in northern Canada from an historical perspective. In particular, Burnett focuses on tracing the impact by federal food subsidy programs on the foodways of northern Indigenous peoples and the roles played by the Northern Department of the Hudson's Bay Company (later the North West Company) since World War II. Burnett's project has been informed by and developed in conjunction with community members. Kelly Skinner has worked closely with a number of First Nations communities in northern Ontario on community-based health and social projects related to food, nutrition, and food security. Her research has included an assessment of the prevalence and severity of food insecurity, critiques of food security measurement tools for northern populations, evaluation of community-led food initiatives, and food costing. For his part, Joseph LeBlanc has a great deal of experience working on food security in the North. His research looks at Indigenous food sovereignty and industrial natural resource management, with a particular focus on food system initiatives in northern Ontario that include community and forest gardening, forest and freshwater foods, and forest food system planning. LeBlanc was also a founding board member and president of True North Community Co-operative.

\section{Food subsidy programs in northern Canada}

After the Second World War, the federal government of Canada created what was officially called the Northern Air Stage Program-hereafter referred to as the Food Mail Program (FMP). From the 1960s, the FMP operated as a transportation subsidy run initially by Canada Post (a crown corporation) and by the Department of Indian and Northern Affairs Canada (INAC) after 1991. Under this program, communities that lacked "year-round surface transportation" could have the cost of shipping food and goods into their communities subsidized. Food eligibility under the program was based on the Nutritious Food Basket, ${ }^{3}$ but also included essential goods

\footnotetext{
${ }^{3}$ According to the Ontario Ministry of Health Promotion, “A Nutritious Food Basket (NFB) is a survey tool that is a measure of the cost of basic healthy eating that represents current nutrition recommendations and average food purchasing patterns. Food costing is used to monitor both affordability and accessibility of foods by relating the cost of the food basket to individual/family incomes. The basket is comprised of 67 items and is designed to reflect an example of an eating pattern that meets Eating Well with Canada's Food Guide, and eating behaviours reflective of
} 
like personal hygiene products, medical and hunting equipment, bottled water, and automobile parts (INAC, 2005; Lawn, 1998).

Before 1991 there were no standard guiding principles used by the federal government to determine which communities were eligible for the FMP (Dargo, 2008). When the FMP was taken over by INAC in 1991, it underwent a series of reviews in order to make the program more cost effective, consistent, and available to all communities rather than a select few (Hill, 1998). For instance, "postage rates for perishable foods were reduced in the territories and increased in the provinces, in order to provide a uniform rate for perishable food shipments to all eligible destinations" (Hill, 1998, p. 177). The range of foods that were eligible for the FMP subsidies were reduced, and instead higher subsidy rates were applied to those perishable foods determined to be more nutritious. In addition to cost, those foods subsidized have also been determined by existing Health Canada recommendations (Lawn, 1998a). Health Canada employs a fairly narrow and evolving definition of what constitutes nutritious food, which rarely reflects local preferences or culture (Interview \#04). A brief glance at the most recent list of eligible "nutritious" foods under NNC illustrates how confusing certain decisions have been. Under NNC, frozen dinners still receive a subsidy while canned soup and stews have been removed; yogurt drinks are subsidized but frozen yogurt is not; and finally, bottled water is no longer subsidized even though as of August 2012, 119 communities First Nations, located primarily in northern Canada, were under "water advisories requiring residents to either boil their water or to heed 'do not drink warnings"” (NNC, 2013d; White, 2012, p. 1).

By 1996, the FMP was provided to " 49 Inuit communities in the Northwest Territories, Quebec, and Labrador (about 30,000 people); 66 First Nation communities in Ontario, Manitoba, Saskatchewan, and Alberta, the western portion of NWT, Yukon, Labrador, and the James Bay and Lower North Shore regions of Quebec (about 37,000 people); and 37 non-Indigenous communities in southern Labrador (about 22,000 people)" (Hill, 1998, p. 177). FMP employees monitored the program closely, and reviewed compliance on an annual basis through onsite surprise visits. Every year government employees conducted food costing —including both perishable and nonperishable items - in approximately forty northern communities and the relevant supply centres/food entry points (AANDC, 2008). The data from this work is available on the AANDC website at: https://www.aadnc-aandc.gc.ca/eng/1100100035986/1100100035987. Moreover, employees of the FMP carried out additional studies to assess the impact of the program on food security and dietary intake in selected communities; from 1991 to 2010 more than thirty reports were released by the FMP. The surprise on-site visits no longer take place, however. Instead, retailers are self-reporting food costs to NNC with no external oversight. As such, there is no way to track whether or not subsidies are being passed on to consumers. The AG's report also concluded that the Contribution Agreements with retailers—-that requires them

the Canadian Community Health Survey.” Ontario, Ministry of Health Promotion, Nutritious Food Basket: Guidance Document (Queen's Printer for Ontario, 2010), 7-8. The Canadian Community Health Survey is not conducted on reserve. 
to provide the Department with monthly reports on food prices-is just a list of food prices, and does not help verify whether the full subsidy is passed on (Auditor General, 2014, p. 7).

\section{Transition from the Food Mail Program to Nutrition North Canada}

The federal government commissioned a report by Graeme Dargo, a partner of Dargo and Associates Consulting Firm, which was carried out in August 2008. Dargo found that although the FMP was necessary for access to affordable and nutritious foods, he believed the program had lost its focus and "vastly exceed[ed] the budget available" further predicting that "the current Program costs will continue to soar and with limited program performance results" (Dargo, 2008, p. 4). He recommended the following: that a market-based system be introduced that would work to develop a new delivery model in partnership with northern retailers; that the base budget of $\$ 27.6$ million be revised; that management systems to ensure retailers would be "refunded for the subsides they would provide to consumers on behalf of Canada" be developed; that the eligibility criteria for communities and foods/goods be reevaluated; that a new country foods initiative be developed; that subsidy rates that have remained the same since 1993 be revised; that consideration be given to transferring the program to the Department of Health and Welfare; and that performance measurement tools be established (Dargo, 2008, p. 5). Dargo concluded that the federal government needed to end the FMP in order to contain the rising costs of the FMP and address the breadth of food insecurity in northern Canada, especially among Indigenous people. While Dargo's report recommended that the FMP be terminated, he also advised that something was still needed to offset the incredibly high costs of food in the North.

In May 2010 INAC announced that they were going to discontinue the FMP and introduce a new program entitled Nutrition North Canada (NNC). Widespread protests delayed the official start of the program until the spring of 2011. The stated goal of NNC was twopronged and remarkably contradictory: to limit the rising costs of the FMP and improve communities' access to perishable nutritious foods. Costs for the program would be contained through two primary means: the elimination of many communities from the program and excluding almost all non-food, but necessary household items such as diapers, dental hygiene products, toilet paper, shampoo, fishing nets, boat motor parts, ammunition, gas (things necessary to pursue hunting and fishing activities), and the large, ambiguous category of “medical devices” (AANDC, 2013).

Community eligibility for subsidies was also redefined. While all remote communities, those without year-round surface transportation, were eligible under the FMP, NNC introduced ineligible, partially eligible, and non-eligible categories. Community eligibility for NNC was based on previous FMP use, focusing specifically on the weight of perishable goods shipped under the FMP during the 2009-10 fiscal period. In order to be eligible for the full subsidy, communities had to have received over $15,000 \mathrm{~kg}$ of perishable foods-or more than \$4 per month per resident in transportation subsidies_-between April 1, 2009 and March 31, 2010 
(NNC, 2014b). Partially eligible communities had to have received between 100 and 14,999 $\mathrm{kg}$ - or more than $\$ 4$ per month per resident in transportation subsidies.

This picture, however, is far more complicated than such criteria suggest, because communities for a number of reasons greatly underused the FMP. First, the FMP was not well promoted even after 1991, and awareness of the program across the North remained extremely poor. An internal review of the FMP in March of 2009 described the program as "invisible", "not widely publicized," and "flying under the radar" (AANDC, 2009). Second, there was a general perception that the FMP was something used only by "white people from the south" (Dargo, 2008; Boult, 2004). Third, in order to place personal orders people needed to use credit cards, which amounted to only about five percent of the program users (Boult, 2004, p. 3). According to the Dargo report, using the personal order component of the program was nearly impossible for many Indigenous community members because they "cannot obtain a credit card, do not own a personal vehicle or cannot communicate in French or English” (p. 17). David Boult noted these concerns four years earlier in a discussion paper on food insecurity in Inuit communities (2004). He reported that extensive paperwork and the need for a credit card limited the number of people who would or could access the program.

Finally, frequently those entities that shipped large volumes of perishable goods into the community on an annual basis - for example, the North West Company (NWC) — did not use the FMP because they found better shipping rates through independent carriers. According to the 2008 Dargo Report there were thirty-one eligible Northern Retailers "who chose not to subscribe to the Program as their current transportation costs are less or equal to the existing Food Mail subsidy rates” (Dargo, 2008, p. 13). Wholesalers and retailers in northern Manitoba indicated that certain Food Mail restrictions (e.g. perishable foods that are subsidized must be shipped separately from ineligible foods and non-perishables) also made using the program complicated and logistically difficult (Lyall, 2004). As a result, in the provincial Norths, large retailers did not generally use the FMP. Instead, locally owned stores, co-operatives, and individual residents were the principal program users in these regions. In regions like Baffin Island, however, the large retailers used the FMP because they were unable to negotiate shipping rates with airlines that were better than what was available under the FMP. Under the FMP, food shipping companies, and not the retail outlets operating in northern communities, applied for the subsidy (Boult, 2004; Lyall, 2004).

Under NNC, there are two levels of the subsidy: a higher amount (Level 1) applies to the most nutritious perishable foods and a lower amount (Level 2) applies to other nutritious perishable foods, to non-perishable foods and to non-food items. Examples of foods qualifying for the higher subsidy level are fresh or frozen fruit and vegetables, milk, and eggs. The amount of the full subsidy for store-bought items at each level are dependent on the remoteness of the community and the subsidy ranges from $\$ 1.20 / \mathrm{kg}$ to $\$ 16.00 / \mathrm{kg}$ for Level 1 items and $\$ 0.05 / \mathrm{kg}$ to $\$ 14.20 / \mathrm{kg}$ for Level 2 items. For partially eligible communities rates are the same for Levels 1 and 2 at $\$ 0.05 / \mathrm{kg}$. A food pricing study of 353 food and household items from a store in a northern Ontario community did not find a difference in price ratio between perishable and non- 
perishable goods (Socha et al., 2011). Yet they did find higher price ratios for items weighing more than one kilogram, fruits and vegetables, and liquid items. It was also noted that these three variables explained only a small proportion of variation in price ratio, and that other factors, such as the shorter shelf life of fruits and vegetables and the expense of shipping heavier items, contributed to the variability (Socha et al., 2011).

Currently, the NWC, the largest retailer of food and goods in the North, receives the vast majority of the NNC subsidy at fifty-nine percent; the second highest retailer is Arctic Cooperatives Ltd., which received thirteen percent of the total subsidy in 2013-2014 (NNC, 20132014a). While we do not know how this picture looks in other regions, in northern Ontario the NWC chose to not partake in the FMP because they could negotiate better shipping rates through regional airlines like Wasaya Airways and Air Creebec. The fact that the NWC did not use the FMP reflects how few communities are currently eligible for subsidies under NNC. In northern Ontario the largest users of the FMP were independent retailers and personal orders. As a result, only eight communities are currently fully eligible at \$0.05 (Level 2) to \$2.60 (Level 1) per kilogram-Attawapiskat, Bearskin Lake, Big Trout Lake, Fort Albany, Fort Severn, Kashechewan, Muskrat Dam, and Peawanuck—and another seven are eligible for a partial subsidy at a mere $\$ 0.05 / \mathrm{kg}$. Table 1 shows the weights of perishable food received by communities in northern Ontario in 2009-10 and the resulting allocation of communities for eligibility to be full, partially, or not subsidized under NNC. 
Table 1: The FMP assessment in 2009-10 for northern Ontario communities and weight of perishable food received to determine eligibility for subsidy during the transition to NNC

\begin{tabular}{|c|c|c|}
\hline Community* & Weight received $(\mathrm{kg}) * *$ & NNC Subsidy $\$ / \mathrm{kg}$ \\
\hline \multicolumn{3}{|c|}{ Fully eligible } \\
\hline & & Level 1/Level 2 \\
\hline Attawapiskat & 68,619 & $1.40 / 0.05$ \\
\hline Bearskin Lake & 35,140 & $1.30 / 0.05$ \\
\hline $\begin{array}{l}\text { Big Trout Lake (Kitchenuhmaykoosib } \\
\text { Inninuwug) }\end{array}$ & 155,862 & $1.60 / 0.05$ \\
\hline Fort Albany & 37,435 & $1.30 / 0.05$ \\
\hline Fort Severn & 109,007 & $2.60 / 0.80$ \\
\hline Kashechewan & 17,147 & $1.30 / 0.05$ \\
\hline Muskrat Dam & 43,442 & $1.50 / 0.05$ \\
\hline Peawanuck & 78,320 & $2.40 / 0.60$ \\
\hline \multicolumn{3}{|c|}{ Partially eligible } \\
\hline Wapekeka (Angling Lake) & 9,577 & 0.05 \\
\hline Kasabonika Lake & 5,975 & 0.05 \\
\hline Kingfisher Lake & 5,188 & 0.05 \\
\hline Pikangikum & 1,623 & 0.05 \\
\hline Sachigo Lake & 5,736 & 0.05 \\
\hline North Caribou Lake & 5,471 & 0.05 \\
\hline Wunnumin Lake & 480 & 0.05 \\
\hline \multicolumn{3}{|c|}{ Ineligible } \\
\hline Cat Lake & 0 & 0 \\
\hline Deer Lake & 0 & 0 \\
\hline Eabametoong & 0 & 0 \\
\hline Sandy Lake & 32 & 0 \\
\hline Keewaywin & 0 & 0 \\
\hline Koocheching & 0 & 0 \\
\hline Neskantaga & 0 & 0 \\
\hline North Spirit Lake & 0 & 0 \\
\hline Marten Falls & 0 & 0 \\
\hline Poplar Hill & 0 & 0 \\
\hline Nibinamik & 0 & 0 \\
\hline Webequie & 0 & 0 \\
\hline Wawakapewin & 0 & 0 \\
\hline MacDowell Lake & 0 & 0 \\
\hline Moose Cree & 0 & 0 \\
\hline Whitewater Lake & 0 & 0 \\
\hline
\end{tabular}

*All communities listed are remote with no year-round road access and are considered fly-in communities.

**Weights based on personal communication with Carol Brillinger from Nutrition North Canada,

December 19, 2011. 
There are several reasons for the non-reported weights during the 2009-10 fiscal year. As mentioned, there were often better rates available from airlines than through the FMP and retailers were limited to airlines that held a Canada Post contract. Therefore, individuals and retailers often opted for better service or prices with other carriers. Many community residents did not place personal orders; and while shopping outside of their community in person, they were unable to utilize the FMP effectively. Unaware of the FMP, many community members shipped food and household items to themselves at full price, and as a result, the weight of their shipments were not counted in 2009-10. Many locally owned stores were also not always aware of how to access the FMP.

In a study conducted in 2011, the grocery store manager of a remote Northwestern Ontario community reported the challenges he faced. The store manager did not have control over the base cost of the items shipped to the store, but she did have control over the volume of each product shipped weekly. The manager's ability to predict sales contributed to the maintenance of lower prices. It was also noted that community members did not blame the store manager for the high cost of food. An independent grocer in Peawanuck, Ontario was interviewed in 2005 at a time when there were only independent locally owned retailers in the community prior to the opening of a Northern Store in 2008. The food items available at the independent store in 2005 consisted primarily of non-perishable and frozen foods. During the interview, the store manager was asked if he tried to bring in perishable produce for his customers. He explained that he had tried for a while, but he regularly received the food in such poor condition that he could not sell it to customers. According to the store manager, often what happened is that he would pay a regional carrier to fly perishable foods into the community, however, if a larger, more influential company wanted to use that plane (for instance resource development companies), his produce would be taken off and put in a freezer to be shipped at a later date. After being frozen and then thawed in transit the perishable food was spoiled (Anonymous, personal communication, July 19, 2005).

\section{Nutrition North Canada's Country Foods Initiative}

One of the flagships of the new NNC program, particularly celebrated by Aboriginal Affairs and Northern Development Canada (AANDC), was the program's Country Foods Initiative (CFI). The CFI is designed to promote access to meats commercially produced in northern Canada. Forest and freshwater foods accessed by individuals are not eligible for subsidy and plant-based foods commercially produced in the north are treated as Level 1 fruits or vegetables.

Regrettably, the country foods initiative is completely ineffective in northern Ontario. Not one community in northern Ontario partakes in the subsidy for country foods (NNC, 2014c).

The rules governing how country food is distributed throughout the North explain the lack of uptake in the program. In order to legally ship forest and freshwater foods, including harvested meats, they must first be certified at one of the "federal regulated plants in the North 
eligible for retail subsidy under NNC” (AANDC, 2011). There are only three licensed food processing facilities that meet the NNC program requirements in the North and they are all located in the territories.

It is also not clear whether government subsidy for country food programs is the best way to provide support as it diminishes the control that communities can exert over their own programs. Country food programs have been defined as "organized initiatives that support people living off the land in order to feed the local community" (Thompson et al., 2011; Thompson et al., 2012). In a similar provincial context, Thompson and colleagues (2012) found that country food programs had the greatest effect on rates of food security in northern Manitoba and indicated that country food programs created, led, and supported by local funding and community direction resulted in food sovereignty. Restricting the flow of country food-by requiring it to be approved through federally licensed processing facilities-greatly reduces the ability of these communities to govern their own country food systems.

\section{Food quality}

The freshness and quality of perishable foods like fruits and vegetables (Lawn et al., 1994) and the decision of northern retailers to sell food that is expired continues to be a major problem in many northern communities in Canada. In an online survey to gather community input about retail and food purchasing experiences in northern Canada, preliminary findings show that one of the top three concerns regarding food purchasing was the quality of the food available for purchase (e.g., freshness, expired food). Eighty-two percent stated that their store often or sometimes sold expired food and $57 \%$ of respondents reported perishable food was not usually in good condition (Burnett \& Skinner, 2015).

Elaine Power (2007), in her background paper on food security for First Nations and Inuit, noted that the FMP also had no effect on the quality, variety, and availability of foods. This continues to be the case under NNC. NNC does not have control over the quality of the subsidized food items that are transported to northern retailers. Irrespective of whether a fresh fruit or vegetable is highly subsidized, its quality remains questionable. Often fruit and vegetables are bruised or inappropriately stored during transport, resulting in reduced quality, often making them unpalatable for consumers. Nor do northern retailers sell damaged food at a reduced price - as is often the case in the south (Burnett \& Skinner, 2015; Feeding My Family, n.d.). The failure to sell foods at reduced or competitive rates may be a function of the lack of competition in most northern communities where customers have no choice and cannot vote with their feet. 


\section{Conclusion}

In December of 2012, Olivier De Schutter, United Nations Special Rapporteur on the Right to Food, submitted his report to the Human Rights Council of the United Nations regarding his trip to Canada. The report observed many of the same concerns about Nutrition North Canada that were identified by the Auditor General of Canada two years later. The right to food is both a human and legal right. According to Jean Ziegler, the right to food "protects the right of all human beings to live in dignity, free from hunger, insecurity and malnutrition. The right to food is not about charity, but about ensuring that all people have the capacity to feed themselves in dignity” (Ziegler, 2015). Moreover, it is a right clearly protected under international law: article 25 of the Universal Declaration on Human Rights and article 11 of the International Covenant on Economic, Social, and Cultural Rights (Ziegler, 2015). In Canada, studies have found that the prevalence of food insecurity was sixty percent of First Nations children in northern Manitoba households, seventy percent of adults living in Nunavut, and seventy percent of households in a remote community in northern Ontario (Skinner et al., 2014; De Schutter, 2012, p. 16). Further, these rates were "six times higher than the national average and represented the highest documented food insecurity rate for any aboriginal population in a developed country" (De Schutter, 2012, p. 16).

Geographically, the North is enormous; it is culturally diverse, it is resource rich, and it faces a range of challenges. In 1670 the Hudson's Bay Company (HBC) became incorporated by the King of England and the Company was granted enormous tracts of land without the consent of Indigenous Nations who had lived on them since time immemorial. After 1821, the HBC operated as a virtual monopoly throughout much of northern Canada, often serving as liaison with Indigenous peoples for the British and later the federal government of Canada, as well as providing essential services normally undertaken by the state.

In 1958, the HBC formally opened their Northern Stores Department, which was an expansion of retail operations in the North on the foundations of their northern fur trade posts. Executives of the HBC and independent investors purchased the Northern Stores Department in 1987. The company trades under the North West Company but is popularly known as the Northern Store (in addition to its many other iterations), and functions as a virtual monopoly throughout northern Canada. The North West Company reported a record trading profit for 2012 of $\$ 134.3$ million. Profits are up twelve percent or $\$ 65$ million from the previous year, and almost eighty percent of this capital was generated from the sale of food (CBC News, 2013). The narrative encouraged by the NWC — in which they describe themselves as doing northerners a favour by selling in a challenging market—is completely false: the NWC makes more than enough profit to justify its continued presence as a retailer in the North, and its expansion into other rural, remote, and Indigenous communities in the South Pacific and Caribbean.

Focusing solely on Nutrition North Canada highlights some of the challenges faced by northern communities struggling to put healthy and affordable food on their tables, but it does not capture the enormity of the situation. In particular, the focus on the arctic regions disregards 
the equally alarming state of food insecurity in the provincial Norths. Our narrative illustrates the situation for northern Ontario and provides a lens for similar scenarios in northern remote communities in other provinces. Food insecurity is a symptom of a larger problem that is rooted in Canada's colonial past. Food subsidy programs are band-aid solutions that do not address the source of the problem, and until Canada acknowledges the actual problem, the symptoms will continue.

\section{References}

AANDC. (2008). Regional results of price surveys. Retrieved from https://www.aadncaandc.gc.ca/eng/1100100035986/1100100035987

AANDC. (2009). Summative Evaluation of INAC's Food Mail Program. Retrieved from https://www.aadnc-aandc.gc.ca/eng/1100100011721/1100100011735

AANDC. (2011). Country foods a priority under Nutrition North Canada. Retrieved from https://www.aadnc-aandc.gc.ca/eng/1305635529864/1305635836396

AANDC. (2013). Changes to the list of items eligible for shipment. Retrieved from http://www.aadnc- andc.gc.ca/eng/1100100015868/1100100015870

APTN. (2014, November 28). What are Northerners and Canadians being fed about Nutrition North? Retrieved from http://aptn.ca/news/2014/11/28/northerners-canadians-fednutrition-north/

Auditor General. (2014). Report of the Auditor General of Canada: Nutrition North Canada-Aboriginal Affairs and Northern Canada. Chapter six. Retrieved from http://www.oag-bvg.gc.ca/internet/docs/parl_oag_201411_06_e.pdf

Bell, P. (2011, February 16). Blame retailers for high Arctic food prices: Aglukkaq. CBC News.

Bevington, D. (2015, February 25). Media Release: Nutrition North funding is a politically motivated shell game, says MP Bevington. http://www.dennisbevington.ca/pdfs/en/2015/release250215-en.pdf

Boult, D. A. (2004). Hunger in the Arctic: Food (in) security in Inuit communities. National Aboriginal Health Organization. Retrieved from https://www.ruor.uottawa.ca/bitstream/10393/30217/1/2004_Inuit_Food_Security.pdf 
Burnett, K., \& Skinner, K. (2015). Food Purchasing Patterns in Northern Communities. Unpublished raw data.

CBC News. (2013, April 25). North West Company reports record profit. Retrieved from http://www.cbc.ca/news/canada/north/north-west-company-reports-record-profit$\underline{1.1375327}$

CBC News. (2014, December 3). Rankin Inlet dump scavenging controversy continues: Are people in Nunavut scavenging for food at landfills? Retrieved from http://www.cbc.ca/news/canada/north/rankin-inlet-dump-scavenging-controversycontinues-1.2859162

Coates, K. (1996). Introduction: Historians and Provincial Norths in Canada. In Ken Coates and William Morrison (eds.), The Historiography of the Provincial Norths. Thunder Bay: Centre for Northern Studies.

Coates, K., \& Poelzer, G. (April 2014). The Next Northern Challenge: The Reality of the Provincial North. A Macdonald-Laurier Institute Publication.

Dargo, G. (2008). Food mail program review: Findings and recommendations by the minister's special representative. Ottawa: Dargo and Associates.

De Schutter, O. (2012). Report of the Special Rapporteur on the right to food, Olivier De Schutter, Addendum. Mission to Canada. Retrieved from http://www.srfood.org/images/stories/pdf/officialreports/20121224_canadafinal_en.pdf

Feeding My Family. (2015). In Facebook [Group]. Retrieved from https://www.facebook.com/groups/239422122837039/

Galloway, T. (2014). Is the Nutrition North Canada retail subsidy program meeting the goal of making nutritious and perishable food more accessible and affordable in the North? Canadian Journal of Public Health, 105(5), e395-e397.

Government of Canada. (2013). About the North: Nunavut. Retrieved from http://www.cannor.gc.ca/eng/1386682445853/1386682479869

Government of Canada. (2014). Regional offices: Ontario Region. Retrieved from https://www.aadnc-aandc.gc.ca/eng/1100100020284/1100100020288 
Hill, F. (1998). Food Mail: the Canadian alternative to food stamps. International Journal of Circumpolar Health, 57(1), 177-181.

Indian and Northern Affairs Canada [INAC]. (2005). Northern food basket. Ottawa: Indian Affairs and Northern Development Canada.

Indian and Northern Affairs Canada [INAC]. (2007). The revised northern food basket. Ottawa: Indian Affairs and Northern Development Canada. Retrieved from http://publications.gc.ca/site/eng/317335/publication.html

Interview \#04 conducted by Kristin Burnett, January 2015.

Lawn, J. (1998). National nutritious food basket. Ottawa: Health Canada.

Lawn, J. \& Hill, F. (1998a). Alternative Northern Food Baskets. Ottawa: Indian and Northern Affairs Canada.

Lawn, J., Langner, N., Brule, D., Thompson, N., \& Hill, F. (1994). The effect of a federal transportation subsidy on nutritional status of Inuit in Canada's Arctic. Arctic Medical Research, 53(Suppl 2), S289-95.

Lyall, D. (2004). Food affordability in Manitoba's north. In Canadian Food Security Assembly 2004, Canadian Centre for Policy Alternatives. pp. 32-53.

Nutrition North Canada [NNC]. (2013-2014a). Data by province or territory and region. Retrieved from http://www.nutritionnorthcanada.gc.ca/eng/1414596570182/14

Nutrition North Canada [NNC]. (2014b). Eligible Communities. Retrieved from http://www.nutritionnorthcanada.gc.ca/eng/1415540731169/1415540791407

Nutrition North Canada [NNC]. (2014c). Communities with set rates for country food subsidies. Retrieved from http://www.nutritionnorthcanada.gc.ca/eng/1415540731169/1415540791407\#tpc2

Nutrition North Canada [NNC]. (2013d). Fact Sheet: Revised Northern Food Basket. Retrieved from http://www.nutritionnorthcanada.gc.ca/eng/1369314079798/1369314090524

Nutrition North Canada [NNC]. (2011). Nutrition North Canada: Subsidized Foods. Retrieved from http://www.nutritionnorthcanada.gc.ca/eng/1369225884611/1369226905551 
Nutrition North Canada [NNC]. (2015). Northern Food Retail Data Collection \& Analysis by Enrg Research Group. Retrieved from http://www.nutritionnorthcanada.gc.ca/eng/1424364469057/1424364505951\#toc

Power, E. (2007). Food security for First Nations and Inuit in Canada background paper. Prepared for the First Nations and Inuit Health Branch, Health Canada.

Skinner K., Hanning R.M., \& Tsuji, L.J.S. (2014). Prevalence and severity of household food insecurity of First Nations people living in an on-reserve, sub-Arctic community within the Mushkegowuk Territory. Public Health Nutrition, 17(1), 31-39.

Socha, T., Chambers, L., Zahaf, M., Abraham, R., \& Fiddler, T. (2011). Food availability, food store management, and food pricing in a northern community First Nation community. International Journal of Humanities and Social Science, 1(11), 49-61.

Thompson, S., Gulrukh, A., Ballard, M., Beardy, B., Islam, D., Lozeznik, V., \& Wong, K. (2011). Is community economic development putting healthy food in the table? Food sovereignty in northern Manitoba's Aboriginal communities. The Journal of Aboriginal Economic Development, 7(2), 14-29.

Thompson, S., Kamal, A.G., Alam, M.A., \& Wiebe, J. (2012). Community development to feed the family in northern Manitoban communities: Evaluating food activities based on their food sovereignty, food security, and sustainable livelihood outcomes. Canadian Journal of Nonprofit and Social Economy Research, 3(2), 43-66.

Valcourt, B. (2014, November 25). Statement by Minister Valcourt in response to the release of the Auditor General's Report on Nutrition North Canada. Retrieved from http://news.gc.ca/web/article-en.do?nid=908419

White, J., Murphy, L., \& N. Spence. (September 2012). Water and Indigenous People: Canada's paradox. The International Indigenous Policy Journal, 3(3), 1-25.

Ziegler, J. (2015). What is the Right to Food? Retrieved from http://www.righttofood.org/workof-jean-ziegler-at-the-un/what-is-the-right-to-food/ 